\title{
Revisiting the beginnings of tin-opacified Islamic glazes
}

\author{
Michael Tite ${ }^{\mathrm{a},{ }^{*},}$, Oliver Watson ${ }^{\mathrm{b}}$, Trinitat Pradell ${ }^{\mathrm{c}}$, Moujan Matin ${ }^{\mathrm{a}}$, Gloria Molina ${ }^{\mathrm{c}}$, \\ Kelly Domoney ${ }^{\mathrm{d}}$, Anne Bouquillon ${ }^{\mathrm{e}}$ \\ ${ }^{a}$ Research Laboratory for Archaeology and the History of Art, Dyson Perrins Building, South Parks Road, Oxford OX1 3QY, UK \\ ${ }^{\mathrm{b}}$ Khalili Research Centre for the Art and Material Culture of the Middle East, 3, St John Street, Oxford OX1 2LG, UK \\ ${ }^{\mathrm{c}}$ Physics Department and Center for Research in Nano-Engineering, Universitat Politècnica de Catalunya, C/Esteve Terrades 8, 08860 Castelldefels, \\ Barcelona, Spain \\ d Centre for Archaeological and Forensic Analysis, Cranfield University, Shrivenham SN6 8LA, UK \\ e C2RMF, Palais du Louvre, 14, quai François Mitterrand, 75001 Paris, France
}

\section{A R T I C L E I N F O}

\section{Article history:}

Received 12 September 2014

Received in revised form

22 January 2015

Accepted 3 February 2015

Available online 14 February 2015

\section{Keywords:}

Opaque yellow glazes

Opaque glass

Lead stannate

Lead antimonate

Islamic

Abbasid

Egypt

Syria

Iraq

Technological transfer

SEM

Hand-held XRF

PIXE

\begin{abstract}
A B S T R A C T
The generally accepted theory is that the demand for Islamic glazed pottery started in Abbasid Iraq in the 9th century AD with the production of a range of glazed wares in response to the import of Chinese stonewares and porcelains. However, Oliver Watson has recently proposed that the demand for Islamic glazed pottery first occurred in Egypt and Syria in the 8th century AD resulting in the production of opaque yellow decorated wares. Using a combination of SEM analysis of polished cross-sections, and surface analysis using hand-held XRF or PIXE, Coptic Glazed Ware from Egypt, Yellow Glazed Ware from Syria, and comparable wares from Samarra, Kish and Susa have been analysed. The analyses show that the opaque yellow decoration was the result of lead stannate particles in a high lead glaze, which it is suggested was produced using a lead-silica-tin mixture. The use of lead stannate in the production of yellow opaque glazes is explained in terms of technological transfer from contemporary Islamic glassmakers who continued the Byzantine tradition of glassmaking. It is further argued that the introduction of opaque yellow glazed pottery into Mesopotamia could have provided the social context for the sudden emergence of tin-opacified white glazed pottery in Abbasid Iraq in the 9th century AD. However, in view of the very different glaze compositions employed for the yellow and white opaque glazes, it seems probable that the white tin-opacified glazes used for Abbasid cobalt blue and lustre decorated wares represent a separate but parallel technological tradition with its origins in the production of Islamic opaque white glass.
\end{abstract}

(C) 2015 Elsevier Ltd. All rights reserved.

\section{Introduction}

The generally accepted theory is that Islamic glazed pottery first blossomed in Abbasid Iraq in the 9th century AD in response to the import of Chinese stonewares and porcelains (Lane, 1947; Northedge, 2001; Tite and Wood, 2005; Wood et al., 2007) and included cobalt blue and lustre decoration on a white tin-opacified glaze. Chinese imports, as indicated by the discovery of the Belitung wreck off the Sumatra coast in 1998, were on a very large scale by the mid 9th century AD. However, Watson (2014) has recently argued that the demand for fine glazed ceramics started earlier and not in Iraq, but in Egypt and Syria. This development was a

\footnotetext{
* Corresponding author.

E-mail address: michael.tite@rlaha.ox.ac.uk (M. Tite).
}

response to the drying up of the supply of fine unglazed tablewares in the eastern Mediterranean when the kilns that supplied the late Antique world with Red Slip wares were destroyed by the arrival of the Arab armies (Hayes, 1972). To fill the gap, potters in Islamic Egypt and Syria developed not only fine painted unglazed wares, but also new glazed types. Thus, Islamic glazed pottery frequently with opaque yellow and green decoration first appeared in Egypt (Coptic Glazed Wares - Scanlon, 1998) and then in Syria (Yellow Glazed Family - Watson, 1999) in the late 7th - 8th century AD. From here, the yellow glaze tradition spread to Mesopotamia where, in the 9th century AD, it could have provided the context for the emergence of a range of white tin-opacified wares, inspired by Chinese imports.

In order to investigate this recent hypothesis, a small group of sherds of Coptic Glazed Ware (CGW) from Egypt and Yellow Glazed Family (YGF) from Syria were analysed in polished section in a 
scanning electron microscope (SEM) with energy-dispersive spectrometry (EDS). These analyses were supplemented by the examination with a binocular microscope and by x-ray diffraction (XRD) measurements. The analytical data were extended by nondestructive surface analyses, using either hand-held $\mathrm{x}$-ray fluorescence (HH-XRF) or proton-induced $\mathrm{x}$-ray emission (PIXE), of further examples of these two wares together with comparable yellow glazed wares from Samarra, Kish and Susa. A total of twenty-seven ceramics were analysed, the primary aim being to establish whether or not the opacifiers used were tin-based (i.e. lead stannate yellow and tin oxide white) as used by Roman and contemporary Byzantine glassmakers, following the switch from the use of antimony-based opacifiers (lead antimonate yellow and calcium antimonate white) by Roman glassmakers around the 4th century AD (Turner and Rooksby, 1959; Tite et al., 2008). In addition a group of three later sherds (Fayyumi Type 1 and related wares) from Egypt were also examined since opaque yellow and green glazes were used in Egypt alongside the production of lustre ware and other white tin-opacified glazed wares introduced, probably in the 9th 10 th century AD, from Iraq.

\section{Experimental procedures}

\subsection{Glazed ceramic samples}

One Egyptian CGW sherd (ALX202) from the sherd collection made from Fustat by the late Alexander Kaczmarczyk (Tite, 2011), and four Syrian YGF sherds (OLW1-4), provided by Oliver Watson, were selected for SEM and binocular microscope examination in polished section, and for XRD measurements (Fig. 1a-e). Surface analyses using either HH-XRF or PIXE were also made on a CGW dish (EA1974.48) in the Ashmolean Museum, Oxford; fourteen YGF sherds from Al Mina (Fig. 2a-b) and four comparable yellow glazed sherds from Samarra and Kish, all in the Victoria and Albert Museum; and three glazed bowls from Susa in the Musée du Louvre. In addition, one sherd (ALX66) from the collection of the late Alexander Kaczmarczyk related to Fayyumi Type 1 ware (Fig. 1f) was analysed by a combination of SEM, binocular microscopy and XRD, and two Fayyumi Type 1 sherds from the V \& A (Fig. 2c-d) were analysed with the HH-XRF. The location of sites referred to in the text including those from which the ceramic samples were obtained are indicated on the map presented in Fig. 3.

The overall dating of Islamic ceramics of this period is based on the archaeological contexts in which the different ceramic types were found, and the dates for these contexts are themselves frequently of limited precision. CGW is found in late 7th and 8th century AD contexts (Scanlon, 1998); the production of the YGF was established across Syria in the second half of the 8th century AD (Whitcomb, 1989; Watson, 1999); and comparable yellow glazed wares in Mesopotamia have been found alongside 9th century AD wares of Samarra type (e.g., copies of Chinese Changsa and sancai, and tin-opacified glazed wares with cobalt blue and lustre decoration) (Watson, 2014). According to Scanlon (1993), the later Egyptian Fayyumi Type 1 wares cannot be more precisely dated than to c.850-1100 AD. Where the sherds analysed in the present paper are without precise provenance (e.g., ALX and OWC sherds), they are dated by means of typological comparison with excavated material.

\subsection{Analytical procedures}

The glaze-body microstructures, and the chemical compositions of the bulk glazes, individual opacifier particles and the bodies for those sherds from which polished sections were prepared were investigated using SEMs at UPC, Barcelona and RLAHA, Oxford. At
UPC, a crossbeam workstation (Zeiss Neon 40) equipped with SEM (Shottky FE) column and EDS (INCAPentaFETx3 detector, $30 \mathrm{~mm}^{2}$, ATW2 window) were employed, and at RLAHA, a JEOL SEM (JSM5910) with Oxford Instruments EDS (INCA 300 System) was employed. Both systems were operated at $20 \mathrm{kV}$ with $120 \mathrm{~s}$ measuring times, and backscattered electron (BSE) images were obtained in order to study the microstructures of cross-sections through the glazes and bodies. Prior to coating for the SEM examination, the cross-sections were examined under a binocular microscope with objectives in the range $1 \times$ to $11.5 \times$. XRD measurements were made on the glaze surfaces of these same sherds using a conventional diffractometer, Bruker D8 with $\mathrm{Cu}-\mathrm{K} \alpha$ $(1.5606 \AA)$ radiation with $4-70^{\circ}$ two theta range, the penetration depth of the X-rays being less than about $100 \mu \mathrm{m}$. Identification of the compounds has been performed based on the Powder Diffraction File (PDF) database from the International Centre for Diffraction Data (ICDD).

Semi-quantitative HH-XRF analysis was performed using an Oxford Instruments X-MET 5100 X-ray fluorescence analyser equipped with a silicon drift detector, rhodium tube and $8 \mathrm{~mm}$ beam diameter (Casadio et al., 2012). The Soil-FP (Fundamental Parameters) mode was selected for all measurements, operating at $45 \mathrm{kV}$ accelerating voltage, $15 \mu \mathrm{A}$ beam current with a $25 \mu \mathrm{m}$ iron filter. In most instances, two 30s measurements were taken from flat areas of the glaze surface. Bruker Artax software (Version 7.0.0) was used to identify spectral lines and calculate peak intensity counts. Because $\mathrm{Pb} \mathrm{L} \alpha$ counts tend to swamp the detector at high lead oxide concentrations, the $\mathrm{Pb}$ Ly peak intensity counts have been used, and these were calculated in Excel using the raw count data and subtracting the background counts.

PIXE analysis was performed using the new AGLAE system, introduced at C2RMF in 2012, in which four detectors consisting of Peltier-cooled SDD are dedicated to high energy X-rays ( $>3 \mathrm{keV}$ ), and another detector is optimized for the measurement of low energy X-rays (1-10 keV) (Pichon et al., 2014). Each analysis was performed by scanning the beam across one $500 \times 500 \mu \mathrm{m}^{2}$ area, in order to minimize the influence of material heterogeneities, and a helium flow ( $2 \mathrm{l} / \mathrm{min}$ ) was maintained in both the particle and X-ray beam paths to minimize energy losses and absorption. The glaze compositions were determined using a $3 \mathrm{MeV}$ proton beam and the major, minor and trace element concentrations were calculated using the TRAUPIXE software (Pichon et al., 2010) with the GUPIXWIN code (Campbell et al., 2010). The DrN geological standard from CRPG was used to validate the results.

\section{Results}

The chemical compositions of the glazes, opacifier particles and bodies for the sherds analysed in polished section by EDS in the SEM, are given in Tables $1-3$. The peak intensity counts resulting from surface analyses of the glazes as determined by HH-XRF are given in Table 4, and for comparative purposes, these analyses include data for sherd ALX202 also analysed in polished section by EDS in the SEM. The chemical compositions of the glazes as determined by surface analysis by PIXE are given in Table 5 .

\subsection{Egyptian CGW, Syrian YGF and related yellow glazed ceramics from Mesopotamia}

On the basis of the analytical data presented in Table 1, it is clear that lead stannate was used as the opacifier in all the yellow CGW and YGF glazes (Fig. 1a-e), and analysis of a selection of the lead stannate particles indicated that they were of the form $\mathrm{Pb}(\mathrm{Sn}, \mathrm{Si}) \mathrm{O}_{3}$ with $\mathrm{Sn} / \mathrm{Si}$ wt\% ratios in the range 1.7-3.8. The green CGW and YGF glazes were all coloured by the addition of a few wt\% of copper 

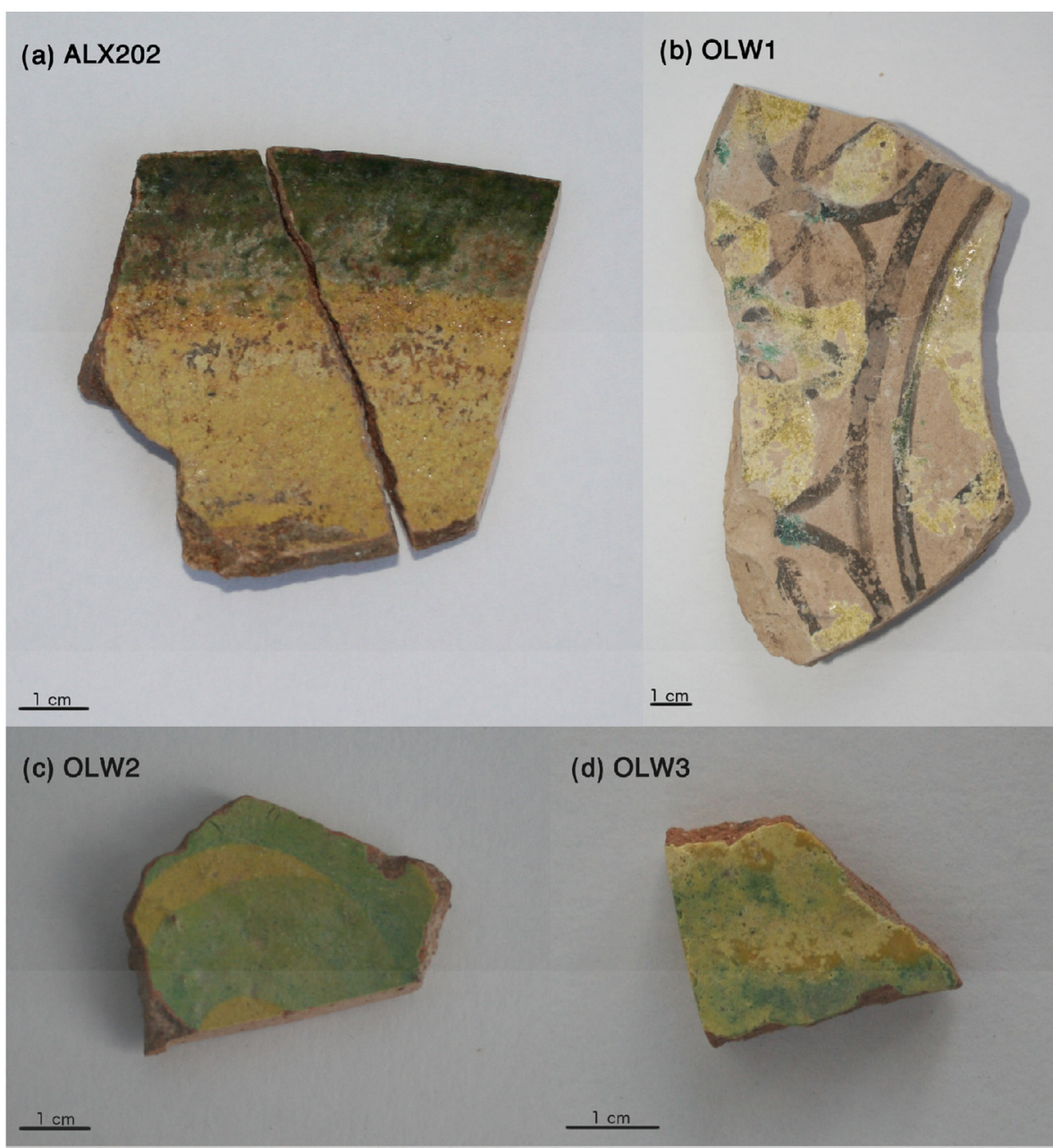

(d) OLW3

(e) OLW4

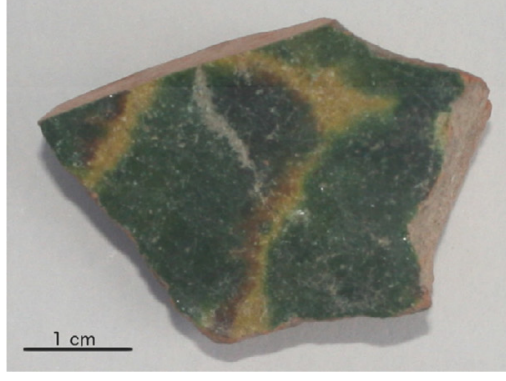

(f) ALX66

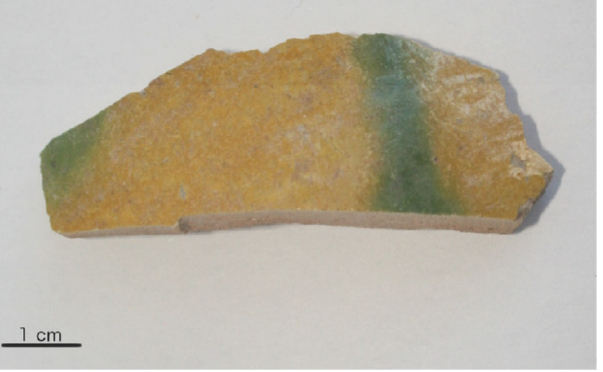

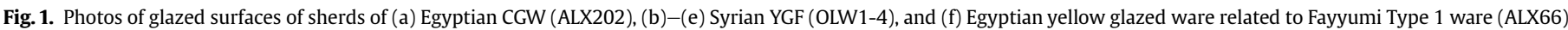
examined with SEM-EDS.

oxide, but they varied in terms of their opacification. The green glazes applied to sherd OLW2 and OLW 3 were again opacified with lead stannate, but no opacifier particles were detected in the green glazes applied to sherds ALX202 and OLW4. The yellow and green glazes were all of the high lead type containing 60-67 wt\% $\mathrm{PbO}$ with alkali content less than about $2 \mathrm{wt} \%\left(\mathrm{Na}_{2} \mathrm{O}\right.$ plus $\left.\mathrm{K}_{2} \mathrm{O}\right)$, and with the exception of ALX202 which contains $4 \mathrm{wt} \% \mathrm{Al}_{2} \mathrm{O}_{3}$, the alumina contents were about $1 \mathrm{wt} \%$ or less. The bulk XRD measurements confirm the presence lead stannate as the principal opacifier (Fig. 4a).

SEM photomicrographs of sections through the glazes into the bodies of the five sherds indicate that the yellow glazes vary in thickness from 75 to $425 \mu \mathrm{m}$ and the green glazes which, with the exception of ALX202, tend to be thicker are in the range from 75 to $500 \mu \mathrm{m}$ (Fig. 5a-e, and Table 1). Lead stannate $\left(\mathrm{Pb}(\mathrm{Sn}, \mathrm{Si}) \mathrm{O}_{3}\right)$ particles can be seen in the SEM in all the yellow glazes, and in the green glazes applied to sherds OLW2 and OLW3. As confirmed at higher magnification, the lead stannate particles are anhedral in form (Fig. 6a). A scatter of quartz particles are also present in several of the glazes (Fig. $5 \mathrm{c}-\mathrm{e}$ ). The extent of the interaction occurring at the interface between the glaze and the body tends to be limited, the greatest interaction being observed for ceramic OLW2 (Fig. 5c-d).

Examination of the glaze sections in a binocular microscope indicated that, for OLW2 and OLW3, the green glazes overly the yellow glazes (Fig. 7a). In contrast, for ALX202 and OLW4, the 


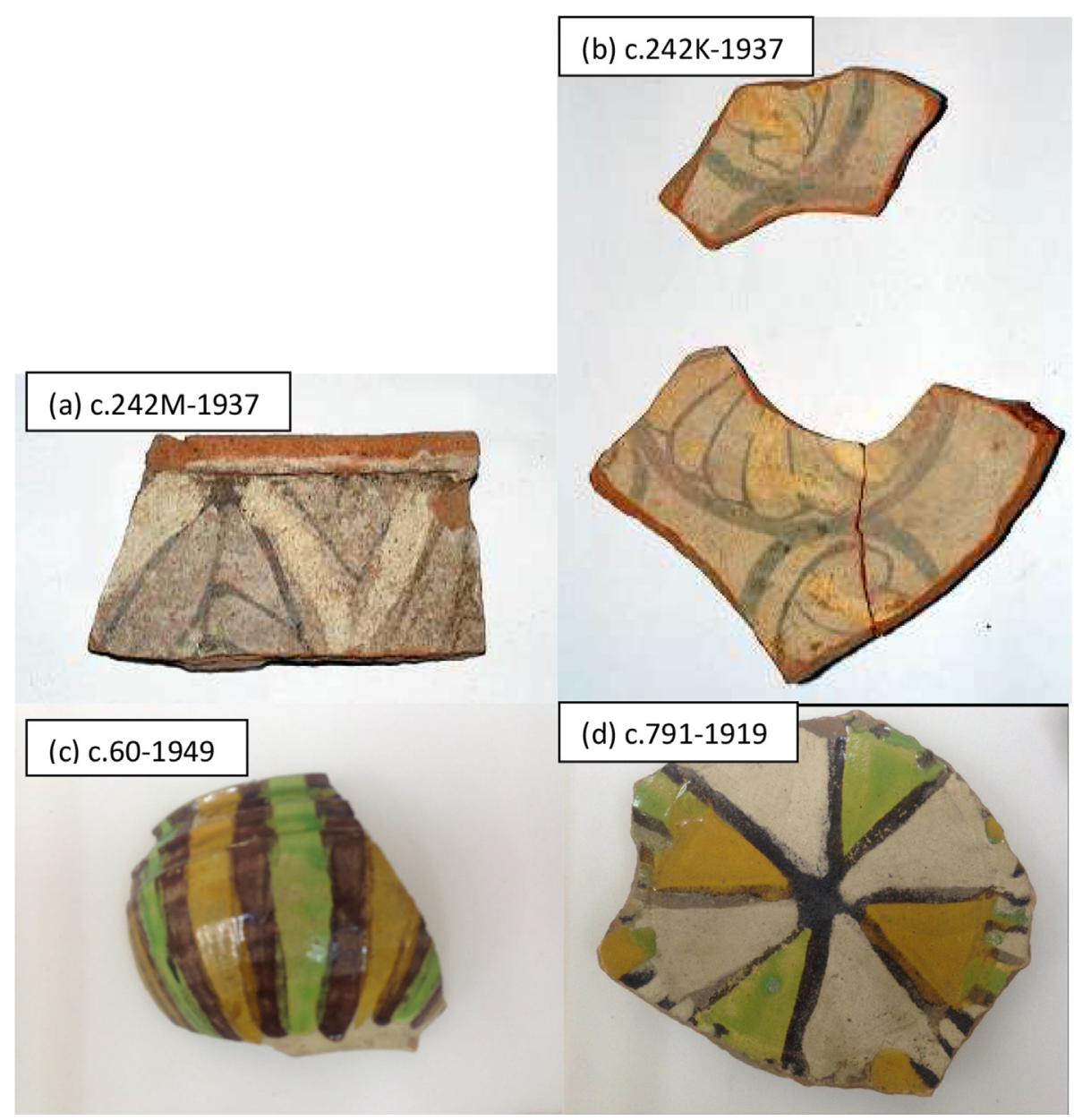

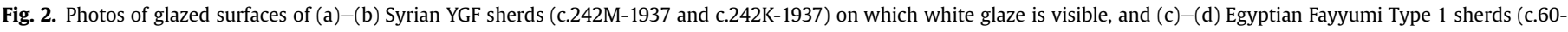
1949 and c.791-1919).

yellow and green glazes were both applied directly onto the bodies with only limited overlap. In the case of OLW4, the brown glaze regions between the green and the yellow glazes are the result of small areas where the green glaze overlies the yellow glaze. Compositional profiles through the thickness of the green glazes indicate that, in all cases, the copper oxide contents are higher at

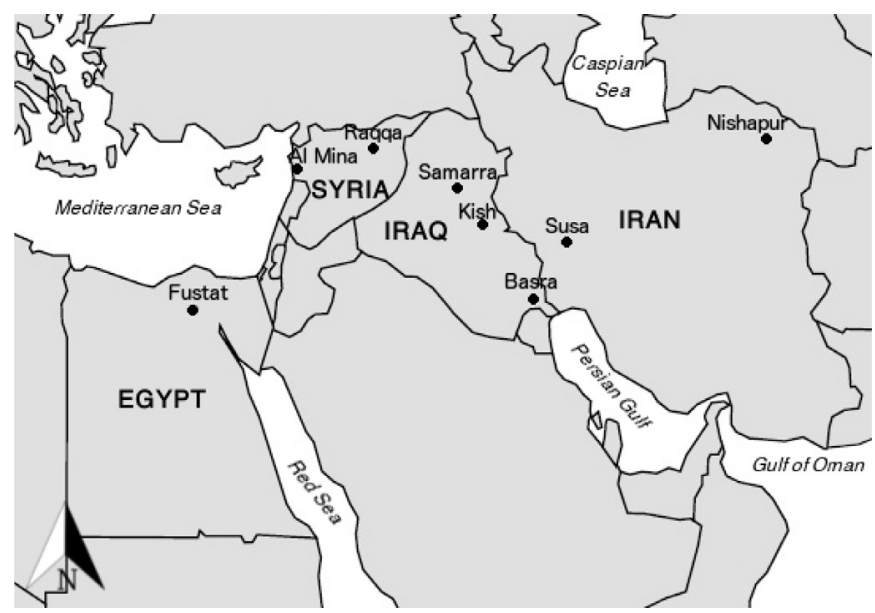

Fig. 3. Map showing location of sites referred to in the text including those from which the ceramic samples were obtained. the front of the glazes as compared to the back adjacent to the bodies (Table 2). However, the gradients are greatest when the green glaze overlies the yellow glaze rather than being adjacent to it, the $\mathrm{CuO}$ wt\% front/back ratios being 2.9 and 2.5 for OLW2 and OLW3 respectively, as compared to 1.3 and 1.6 for ALX202 and OLW4 respectively. The profiles also show that, as a result of interaction between the glaze and body, the alumina content is higher at the back of the glaze as compared to the front.

On the basis of the analytical data presented in Table 3, it is seen that the body of the Egyptian CGW ceramic (ALX202) was produced from an aluminium-rich clay containing about $24 \mathrm{wt} \% \mathrm{Al}_{2} \mathrm{O}_{3}$. In contrast, those of the Syrian YGF ceramics were produced from calcareous clays containing $12-25 \mathrm{wt} \% \mathrm{CaO}$. As observed in the SEM, the microstructure associated with the aluminium-rich body (ALX202) is more compacted (Fig. 8a) than the porous microstructure associated with the calcareous clay body (OLW1) (Fig. 8b). In the calcareous clay bodies, there is a fairly extensive network of glass phase bonding together the non-plastic quartz and feldspar particles, suggesting firing temperatures at least in the range $850-900{ }^{\circ} \mathrm{C}$ (Maniatis and Tite, 1981). In contrast, the ALX202 body is only slightly vitrified but, because of its high aluminium content, the firing temperature was probably at least $800-850{ }^{\circ} \mathrm{C}$.

\subsection{1. $H H-X R F$ results}

The surface glaze analyses determined by HH-XRF (Table 4) indicate that the opacifiers used in all the yellow and green glazes applied to the CGW dish (Ashmolean - EA1974.48)), the Syrian YGF 
Table 1

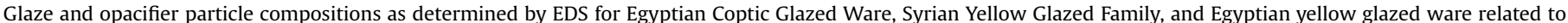
Fayyumi Type 1 ware.

\begin{tabular}{|c|c|c|c|c|c|c|c|c|c|c|c|c|c|c|c|c|c|c|c|}
\hline \multirow[t]{2}{*}{ Code } & \multirow[t]{2}{*}{ Colour } & \multirow[t]{2}{*}{ Thickness $(\mu \mathrm{m})$} & \multicolumn{13}{|c|}{ Glaze composition (normalised 100 wt\%) } & \multirow[t]{2}{*}{$\begin{array}{l}\text { Opacifier particles } \\
\text { observed in SEM }\end{array}$} & \multicolumn{3}{|c|}{$\begin{array}{l}\text { Particle } \\
\text { composition }\end{array}$} \\
\hline & & & $\mathrm{SiO}_{2}$ & $\mathrm{PbO}$ & $\mathrm{SnO}_{2}$ & $\mathrm{Sb}_{2} \mathrm{O}_{5}$ & $\mathrm{Na}_{2} \mathrm{O}$ & $\mathrm{K}_{2} \mathrm{O}$ & $\mathrm{CaO}$ & $\mathrm{MgO}$ & $\mathrm{Al}_{2} \mathrm{O}_{3}$ & $\mathrm{MnO}$ & $\mathrm{FeO}$ & $\mathrm{CuO}$ & $\mathrm{ZnO}$ & & $\mathrm{PbO}$ & $\mathrm{SnO}_{2}$ & $\mathrm{SiO}_{2}$ \\
\hline \multicolumn{20}{|c|}{ Egyptian Coptic Glazed Ware (CGW) } \\
\hline \multirow{2}{*}{ ALX202 } & Yellow & 75 & 29.4 & 63.3 & 2.1 & bd & 0.1 & 0.1 & 0.2 & 0.1 & 4.2 & bd & 0.6 & bd & 0.1 & $\mathrm{~Pb}(\mathrm{Sn}, \mathrm{Si}) \mathrm{O}_{3}$ & 62 & 30 & 8 \\
\hline & Green & 75 & 27.6 & 60.2 & 0.2 & bd & 0.1 & 0.2 & 2.3 & 0.3 & 4.2 & bd & 1.0 & 3.5 & 0.3 & None & & & \\
\hline \multicolumn{20}{|c|}{ Syrian Yellow Glazed Family (YGF) } \\
\hline OLW1 & Yellow & 150 & 26.0 & 62.8 & 3.8 & bd & 1.1 & 0.8 & 1.5 & 0.2 & 1.2 & 0.2 & 2.3 & bd & bd & $\mathrm{Pb}(\mathrm{Sn}, \mathrm{Si}) \mathrm{O}_{3}$ & 67 & 22 & 11 \\
\hline \multirow[t]{2}{*}{ OLW2 } & Yellow & 75 & 31.0 & 63.5 & 3.3 & bd & bd & 0.1 & 0.8 & 0.2 & 0.9 & bd & 0.2 & 0.1 & bd & $\mathrm{Pb}(\mathrm{Sn}, \mathrm{Si}) \mathrm{O}_{3}$ & 64 & 24 & 12 \\
\hline & Green & 100 & 28.8 & 64.2 & 3.6 & bd & bd & bd & 0.8 & 0.3 & 0.9 & bd & 0.1 & 1.3 & bd & $\mathrm{Pb}(\mathrm{Sn}, \mathrm{Si}) \mathrm{O}_{3}$ & 62 & 24 & 14 \\
\hline \multirow[t]{2}{*}{ OLW3 } & Yellow & 425 & 29.9 & 61.5 & 5.8 & bd & 0.3 & 0.4 & 0.8 & 0.3 & 0.5 & bd & 0.4 & 0.1 & bd & $\mathrm{Pb}(\mathrm{Sn}, \mathrm{Si}) \mathrm{O}_{3}$ & 65 & 25 & 10 \\
\hline & Green & 500 & 28.8 & 60.3 & 5.0 & bd & 0.2 & 0.2 & 0.8 & 0.3 & 0.7 & bd & 1.1 & 2.5 & 0.3 & $\mathrm{~Pb}(\mathrm{Sn}, \mathrm{Si}) \mathrm{O}_{3}$ & 65 & 26 & 9 \\
\hline \multirow[t]{3}{*}{ OLW4 } & Yellow & 125 & 26.5 & 67.3 & 2.2 & bd & 0.1 & 0.2 & 1.7 & 0.5 & 0.8 & bd & 0.6 & 0.2 & bd & $\mathrm{Pb}(\mathrm{Sn}, \mathrm{Si}) \mathrm{O}_{3}$ & 64 & 26 & 10 \\
\hline & Brown & 150 & 27.7 & 65.6 & 1.9 & bd & 0.2 & 0.3 & 1.8 & 0.5 & 0.7 & 0.2 & 0.5 & 0.6 & 0.1 & $\mathrm{~Pb}(\mathrm{Sn}, \mathrm{Si}) \mathrm{O}_{3}$ & 65 & 25 & 10 \\
\hline & Green & 175 & 24.5 & 66.3 & 0.5 & bd & bd & 0.2 & 1.8 & 0.6 & 0.8 & bd & 0.5 & 3.7 & 1.0 & None & & & \\
\hline \multicolumn{20}{|c|}{ Egyptian yellow glazed ware related to Fayyumi Type 1 ware } \\
\hline \multirow[t]{2}{*}{ ALX66 } & Yellow & 225 & 36.6 & 50.9 & 0.3 & 0.9 & 1.6 & 2.1 & 2.0 & 0.2 & 3.1 & 0.1 & 2.3 & bd & bd & $\mathrm{Pb}_{2} \mathrm{Sb}_{2} \mathrm{O}_{7}$ & & * & \\
\hline & Green & 150 & 37.3 & 50.6 & 0.2 & 0.6 & 1.3 & 1.7 & 1.7 & 0.4 & 2.5 & 0.1 & 1.6 & 1.4 & 0.6 & $\mathrm{~Pb}_{2} \mathrm{Sb}_{2} \mathrm{O}_{7}$ & & $*$ & \\
\hline
\end{tabular}

*Typical formula of lead antimonate particles is $\mathrm{Pb}_{2} \mathrm{Sb}_{1.6} \mathrm{Fe}_{0.1} \mathrm{Ti}_{0.3} \mathrm{Ca}_{0.6} \mathrm{O}_{6.6}$.

sherds (Al Mina) as well as to related sherds from Samarra and Kish are tin-based. Since the peak intensity counts for Pb-Ly, Sn-Ka, and $\mathrm{Cu}-\mathrm{K} \alpha$ for all these glazes are comparable to the counts for ALX202 glaze, we can infer from its EDS analysis (Table 1) that the glazes analysed by the HH-XRF are of the high lead type containing around $60 \mathrm{wt} \% \mathrm{PbO}$ together with a few wt\% tin oxide, and where present, a few wt\% copper oxide.

The extent to which tin oxide was used to produce opacified white glazes seems to have been very limited. No white glazes had been applied to the Egyptian CGW and Syrian YGF ceramics analysed by SEM and XRD. For the sherds analysed by HH-XRF, only the white glaze applied to Syrian YGF ceramic c.242M-1937 (Fig. 2a) contained significant tin (peak intensity counts for $\mathrm{Sn}-\mathrm{K} \alpha$ equal to $24.8 \times 10^{3}$ ), the peak intensity counts for $\mathrm{Sn}-\mathrm{K} \alpha$ being very low $\left(2.9 \times 10^{3}\right.$ and $3.7 \times 10^{3}$ respectively) for the white glazes applied to the CGW dish (Ashmolean - EA1974.48) and the Syrian YGF ceramic c.242K-1937 (Fig. 2b). Similarly, no white glazes had been applied to the yellow glazed ceramics from Samarra and Kish analysed by HH-XRF.

\subsubsection{PIXE results}

The surface glaze analyses determined by PIXE (Table 5) indicate that the opacifiers used in the yellow, green and brown glazes applied to two bowls (MAOS576 and MAOS37) from Susa are again tin-based and that glazes are of the high lead type containing $50-60$ wt\% PbO with alkali content less than about $1.5 \mathrm{wt} \%\left(\mathrm{Na}_{2} \mathrm{O}\right.$ plus $\mathrm{K}_{2} \mathrm{O}$ ). In contrast, the green and brown glazes applied to the third bowl (MAOS439) contain very much lower tin oxide contents, and the tin oxide content of the white glaze is below detection. Furthermore, the green and brown glazes applied to this bowl are

Table 2

Copper oxide and alumina wt\% profiles from back to front of green glazes as determined by EDS.

\begin{tabular}{|c|c|c|c|c|c|c|c|c|c|c|}
\hline \multirow[t]{3}{*}{ Location } & \multicolumn{10}{|l|}{ wt\% } \\
\hline & \multicolumn{2}{|c|}{ ALX202 } & \multicolumn{2}{|c|}{ OLW2 } & \multicolumn{2}{|c|}{ OLW3 } & \multicolumn{2}{|c|}{ OLW4 } & \multicolumn{2}{|c|}{ ALX66 } \\
\hline & $\mathrm{CuO}$ & $\mathrm{Al}_{2} \mathrm{O}_{3}$ & $\mathrm{CuO}$ & $\mathrm{Al}_{2} \mathrm{O}_{3}$ & $\mathrm{CuO}$ & $\mathrm{Al}_{2} \mathrm{O}_{3}$ & $\mathrm{CuO}$ & $\mathrm{Al}_{2} \mathrm{O}_{3}$ & $\mathrm{CuO}$ & $\mathrm{Al}_{2} \mathrm{O}_{3}$ \\
\hline \multirow[t]{4}{*}{ Back } & 2.8 & 5.3 & 1.0 & 4.5 & 1.0 & 0.8 & 2.8 & 4.2 & 1.5 & 5.2 \\
\hline & 2.7 & 4.4 & 1.4 & 2.0 & 1.7 & 0.4 & 3.1 & 4.0 & 1.5 & 4.2 \\
\hline & 2.7 & 3.3 & 1.9 & 1.1 & 2.5 & 0.4 & 3.8 & 1.7 & 1.7 & 4.0 \\
\hline & 3.1 & 3.3 & 2.9 & 0.5 & & & 4.5 & 1.7 & 2.0 & 4.0 \\
\hline Front & 3.7 & 3.3 & & & & & & & & \\
\hline
\end{tabular}

of the lead-alkali type containing only $20-25 \mathrm{wt} \% \mathrm{PbO}$ together about $6 \mathrm{wt} \%\left(\mathrm{Na}_{2} \mathrm{O}+\mathrm{K}_{2} \mathrm{O}\right)$, and in the white glaze, the lead oxide content is less that the alkali content.

\subsection{Egyptian Fayyumi Type 1 and related wares}

On the basis of the analytical data presented in Table 1, it is clear that lead antimonate, rather than lead stannate, provided the opacifier in the yellow glaze applied to sherd ALX66 from Egypt which is related to Fayyumi Type 1 ware (Fig. 1f). The green glaze, which is also opacified with lead antimonate, is again coloured by the addition of a small amount of copper oxide. Analysis of individual lead antimonate particles indicated that they are of the form $\mathrm{Pb}_{2}(\mathrm{Sb}, \mathrm{Fe}, \mathrm{Ti})_{2} \mathrm{O}_{7}$ with calcium and tin also substituting in some cases. A typical formula for these particles is $\mathrm{Pb}_{2} \mathrm{Sb}_{1.6} \mathrm{Fe}_{0.1} \mathrm{Ti}_{0.3} \mathrm{O}_{6.6}$. Both glazes have lower lead oxide (51 cf. 60-67 wt\% PbO), higher silica (37 cf. 26-31 wt\% $\mathrm{SiO}_{2}$ ), and higher alkali (3-4 cf. less than $2 \mathrm{wt} \% \mathrm{Na}_{2} \mathrm{O}$ plus $\mathrm{K}_{2} \mathrm{O}$ ) contents than those of CGW and YGF. As in the case of glaze ALX202, they also contain significant aluminium ( $3 \mathrm{wt} \% \mathrm{Al}_{2} \mathrm{O}_{3}$ ). The bulk XRD measurements confirm the presence of lead antimonate as the principal opacifier (Fig. 4b).

SEM photomicrographs of section through ALX66 glaze indicate that the yellow glaze $(225 \mu \mathrm{m})$ is thicker than the green glaze $(150 \mu \mathrm{m})$ (Fig. $5 \mathrm{f}$ and Table 1$)$, and that a high proportion of the $\mathrm{Pb}_{2} \mathrm{Sb}_{2} \mathrm{O}_{7}$ particles are euhedral in form (Fig. 6b). Examination of the glaze section in a binocular microscope indicated that the yellow and green glazes were both applied directly onto the body,

Table 3

Body compositions as determined by EDS for Egyptian Coptic Glazed Ware, Syrian Yellow Glazed Family, and Egyptian yellow glazed ware related to Fayyumi Type 1 ware.

\begin{tabular}{llllllllll}
\hline Code & \multicolumn{7}{l}{ Body composition (normalised 100 wt\%) } \\
\cline { 2 - 9 } & $\mathrm{SiO}_{2}$ & $\mathrm{Al}_{2} \mathrm{O}_{3}$ & $\mathrm{Na}_{2} \mathrm{O}$ & $\mathrm{K}_{2} \mathrm{O}$ & $\mathrm{MgO}$ & $\mathrm{CaO}$ & $\mathrm{TiO}_{2}$ & $\mathrm{FeO}$ & $\mathrm{PbO}$ \\
\hline $\begin{array}{l}\text { Egyptian Coptic Glazed Ware (CGW) } \\
\text { ALX202 }\end{array}$ & 66.4 & 23.6 & 0.7 & 1.4 & 0.7 & 1.2 & 1.9 & 4.2 & bd \\
Syrian Yellow Glazed Family (YGF) & & & & & \\
OLW1 & 57.9 & 13.6 & 2.1 & 2.7 & 3.2 & 12.1 & 0.6 & 5.3 & 2.5 \\
OLW2 & 46.9 & 12.3 & 1.2 & 2.6 & 3.7 & 24.7 & 1.2 & 7.1 & 0.2 \\
OLW3 & 53.2 & 12.2 & 1.8 & 2.8 & 5.0 & 17.8 & 0.8 & 6.0 & 0.4 \\
OLW4 & 49.1 & 12.1 & 1.6 & 3.1 & 5.1 & 21.4 & 0.8 & 6.7 & 0.1 \\
Egyptian yellow glazed ware related to Fayyumi Type 1 ware & & \\
ALX66 & 57.1 & 11.8 & 1.4 & 1.6 & 2.7 & 17.0 & 1.0 & 6.6 & 0.6 \\
\hline
\end{tabular}


Table 4

Glaze compositions as determined by HH-XRF for Egyptian Coptic Glazed Ware, Syrian Yellow Glazed Family, related yellow glazed sherds from Mesopotamia, and Egyptian Fayyumi Type 1 ware.

\begin{tabular}{|c|c|c|c|c|c|c|c|}
\hline \multirow[t]{2}{*}{ Code } & \multirow[t]{2}{*}{ Colour $^{\mathrm{a}}$} & \multicolumn{6}{|c|}{ Peak intensity counts (divided by 1000 ) } \\
\hline & & $\mathrm{Pb}$ Ly & Sn $K \alpha$ & $\mathrm{Cu} \mathrm{K} \alpha$ & $\mathrm{Zn} \mathrm{K} \alpha$ & Fe $K \alpha$ & $\mathrm{Sb} \mathrm{K} \alpha$ \\
\hline \multicolumn{8}{|c|}{ Egyptian Coptic Glazed Ware (CGW) } \\
\hline \multirow[t]{2}{*}{ ALX202 } & $\mathrm{Y}$ & 29.9 & 21.5 & 0.2 & 0.7 & 9.1 & \\
\hline & G & 21.0 & 14.0 & 42.7 & 7.0 & 16.8 & \\
\hline \multirow{3}{*}{$\begin{array}{l}\text { Ashmolean dish } \\
\text { (EA1974.48) }\end{array}$} & $\mathrm{Y}$ & 23.5 & 19.4 & 0.9 & 0.3 & 7.0 & \\
\hline & G & 20.4 & 8.9 & 40.9 & 6.9 & 12.9 & \\
\hline & W & 12.9 & 2.9 & 5.3 & 1.6 & 46.8 & \\
\hline \multicolumn{8}{|c|}{ Syrian Yellow Glazed Family (YGF) from Al Mina (V \& A) } \\
\hline \multirow[t]{2}{*}{ c. $242-1937$} & Y & 21.4 & 13.7 & 0.4 & 0.3 & 9.4 & \\
\hline & G & 23.0 & 17.4 & 30.0 & 0.7 & 8.1 & \\
\hline \multirow[t]{2}{*}{ c.242F-1937 } & $\mathrm{Y}$ & 26.1 & 29.4 & 0.3 & - & 2.6 & \\
\hline & G & 25.9 & 14.5 & 33.9 & 0.6 & 2.5 & \\
\hline \multirow[t]{2}{*}{ c. $242 \mathrm{~K}-1937$} & Y & 19.1 & 22.9 & 0.2 & - & 7.2 & \\
\hline & W & 9.2 & 3.7 & 0.5 & 0.2 & 35.7 & \\
\hline \multirow[t]{2}{*}{ c. $242 \mathrm{M}-1937$} & G & 22.0 & 12.3 & 8.8 & 0.7 & 12.5 & \\
\hline & W & 19.1 & 24.8 & 1.5 & 0.5 & 10.3 & \\
\hline c. $242 A-1937$ & $\mathrm{Y}$ & 21.0 & 17.6 & 3.0 & 0.2 & 11.6 & \\
\hline c. 242B-1937 & $\mathrm{Y}$ & 21.2 & 14.0 & 0.2 & 0.1 & 10.7 & \\
\hline c. $242 C-1937$ & $\mathrm{Y}$ & 17.0 & 8.3 & 0.5 & 0.2 & 19.2 & \\
\hline c.242D-1937 & $\mathrm{Y}$ & 24.0 & 27.6 & 0.1 & - & 2.0 & \\
\hline c. $242 \mathrm{E}-1937$ & $\mathrm{Y}$ & 15.0 & 10.0 & 1.0 & - & 4.4 & \\
\hline c. $242 \mathrm{H}-1937$ & $\mathrm{Y}$ & 22.5 & 21.8 & 0.1 & 0.1 & 4.5 & \\
\hline c.242J-1937 & $\mathrm{Y}$ & 24.0 & 26.2 & 0.4 & - & 2.6 & \\
\hline c. $244 \mathrm{~A}-1937$ & $\mathrm{Y}$ & 22.2 & 15.5 & 2.4 & 0.2 & 4.4 & \\
\hline c. $244 \mathrm{~B}-1937$ & $\mathrm{Y}$ & 22.7 & 21.8 & 1.2 & 1.0 & 1.5 & \\
\hline \multirow[t]{2}{*}{ c.244D-1937 } & $\mathrm{Y}(\mathrm{Bk})$ & 21.4 & 13.7 & 0.2 & 0.6 & 3.2 & \\
\hline & $\mathrm{Y}(\mathrm{Frt})$ & 24.5 & 22.9 & 0.3 & 0.4 & 1.7 & \\
\hline \multicolumn{8}{|c|}{ Yellow glazed, Relief Moulded Ware from Samarra (V \& A) } \\
\hline c.708-1922 & Y & 24.9 & 20.0 & 0.2 & - & 5.4 & \\
\hline c.724-922 & $\mathrm{Y}$ & 24.1 & 21.9 & 0.1 & - & 5.6 & \\
\hline \multicolumn{8}{|c|}{ Yellow glazed ware from Kish $(\mathrm{V} \& \mathrm{~A})$} \\
\hline c.262-1931 & $\mathrm{Y}$ & 24.6 & 23.4 & 1.1 & - & 1.6 & \\
\hline c.262-1931 (A) & Y & 26.2 & 25.6 & 1.4 & - & 1.6 & \\
\hline \multicolumn{8}{|c|}{ Egyptian Fayyumi Type 1 ware (V\&A) } \\
\hline \multirow[t]{2}{*}{ c.60-1949 } & $\mathrm{Y}$ & 21.9 & 7.9 & 1.3 & 0.3 & 18.9 & 3.3 \\
\hline & G & 22.6 & 10.2 & 12.2 & 2.8 & 3.2 & 2.5 \\
\hline \multirow[t]{3}{*}{ c.791-1919 } & $\mathrm{Y}$ & 23.8 & 12.1 & 2.5 & 0.1 & 15.8 & 3.9 \\
\hline & G & 22.7 & 10.5 & 12.8 & 0.0 & 3.5 & 3.7 \\
\hline & W & 18.2 & 95.1 & 0.5 & 0.3 & 4.1 & \\
\hline
\end{tabular}

a $\mathrm{Y}$ - yellow, G - green, W-white.

with the yellow glaze adjacent to the green glaze (Fig. 7b). However, compositional profiles through the green glaze again show that the copper oxide content is higher at the front as compared to the back of the glaze, with a $\mathrm{CuO}$ wt\% front/back ratio of 1.3. (Table 2).

Although also found at Fustat in Egypt, analysis of the ALX66 body indicates that, in contrast to the ALX202 body, it was produced using a calcareous clay containing 17 wt\% CaO (Table 3). As observed in the SEM, the body exhibits the porous microstructure associated with calcareous clays, and the vitrification is fairly

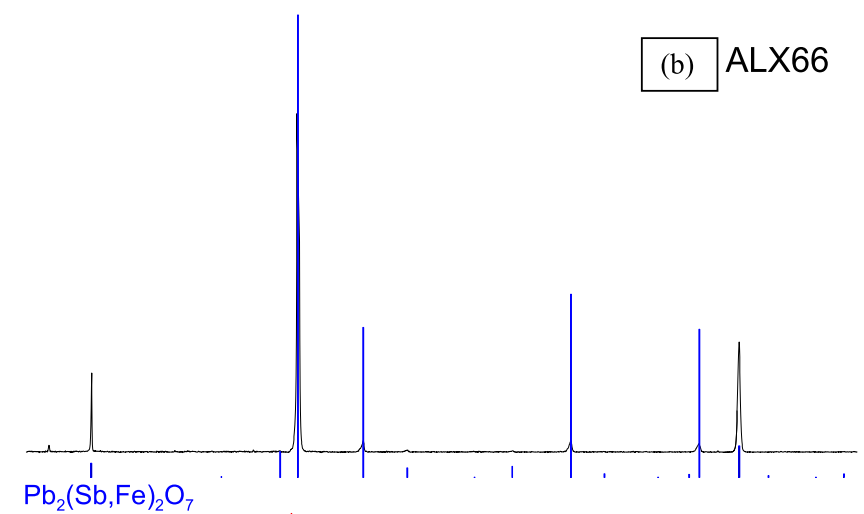

(a) $\mathrm{ALX} 202$

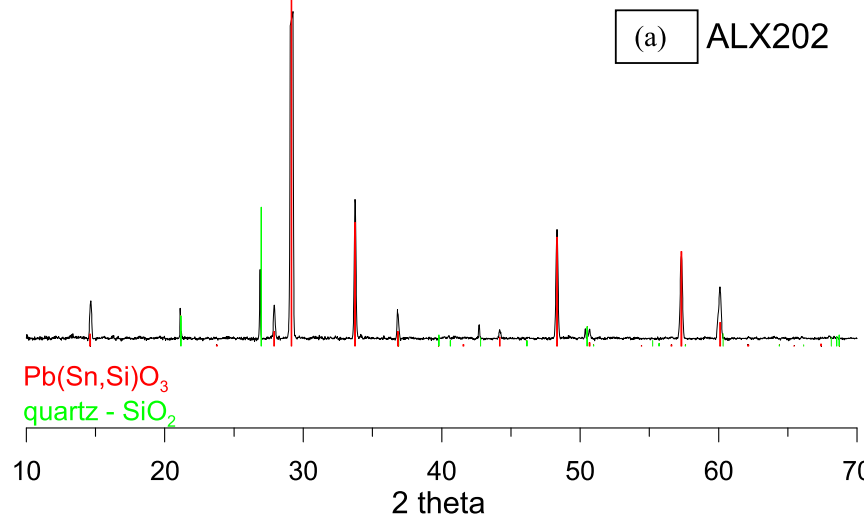

Fig. 4. XRD spectra for (a) ALX202 yellow glaze showing presence of lead stannate and quartz, and (b) ALX66 yellow glaze showing presence of lead antimonate.

extensive (Fig. 8c), again suggesting a firing temperature at least in the range $850-900{ }^{\circ} \mathrm{C}$ (Maniatis and Tite, 1981).

The surface glaze analyses determined by HH-XRF (Table 4) indicate that a combination of tin- and antimony-based opacifiers were used in the yellow and green glazes applied to the two Fayyumi Type 1 ceramics from Egypt (Fig. 2c-d). In contrast to the ALX66 glazes in which the antimony contents are greater than the tin contents, the $\mathrm{Sn}-\mathrm{K} \alpha$, and $\mathrm{Sb}-\mathrm{K} \alpha$ peak intensity counts suggest that tin contents could be greater than the antimony contents for the Fayyumi Type 1 glazes, but quantitative analysis is necessary to confirm this proposed difference. Also, since there are no SEM photomicrographs for these ceramics, we have no information on the distribution of tin and antimony between lead stannate, lead antimonate and tin oxide particles. However, in spite of the inclusion of antimony in the yellow and green glazes, the white glaze applied to one of these ceramics is exclusively tin-opacified (peak intensity counts for $\mathrm{Sn}-\mathrm{K} \alpha$ equal to $\left.95.1 \times 10^{3}\right)$.

Table 5

Glaze compositions as determined by PIXE for glazed bowls from Susa, Iran.

\begin{tabular}{|c|c|c|c|c|c|c|c|c|c|c|c|c|}
\hline \multirow[t]{2}{*}{ Code } & \multirow[t]{2}{*}{ Colour } & \multicolumn{11}{|c|}{ Glaze composition (normalised 100 wt\%) } \\
\hline & & $\mathrm{SiO}_{2}$ & $\mathrm{PbO}$ & $\mathrm{SnO}_{2}$ & $\mathrm{Na}_{2} \mathrm{O}$ & $\mathrm{K}_{2} \mathrm{O}$ & $\mathrm{CaO}$ & $\mathrm{MgO}$ & $\mathrm{Al}_{2} \mathrm{O}_{3}$ & $\mathrm{FeO}$ & $\mathrm{CuO}$ & $\mathrm{ZnO}$ \\
\hline \multirow[t]{2}{*}{ MAOS 576} & Yellow & 33.9 & 58.6 & 4.3 & 0.4 & 0.6 & 1.1 & 0.3 & 0.5 & 0.2 & 0.1 & $<0.05$ \\
\hline & Green & 41.4 & 51.0 & 1.5 & 0.3 & 1.2 & 0.9 & 0.4 & 0.8 & 0.3 & 2.0 & 0.2 \\
\hline \multirow[t]{3}{*}{ MAOS 37} & Yellow & 31.6 & 55.7 & 4.4 & 0.2 & 0.7 & 5.4 & 0.4 & 0.8 & 0.6 & 0.1 & $<0.05$ \\
\hline & Green & 28.0 & 59.4 & 1.8 & 0.1 & 0.6 & 5.2 & 0.4 & 0.9 & 0.3 & 3.0 & 0.4 \\
\hline & Brown & 37.2 & 56.5 & 0.8 & 0.3 & 0.7 & 2.3 & 0.3 & 0.9 & 0.8 & 0.2 & $<0.05$ \\
\hline \multirow[t]{3}{*}{ MAOS 439} & Green & 53.6 & 21.0 & 0.4 & 1.7 & 4.0 & 6.6 & 1.8 & 2.4 & 1.0 & 7.5 & $<0.05$ \\
\hline & Brown & 50.1 & 24.2 & 0.2 & 2.1 & 3.5 & 5.7 & 1.6 & 1.8 & 8.7 & 2.0 & $<0.05$ \\
\hline & White & 72.0 & 5.2 & nd & 1.9 & 5.7 & 7.7 & 1.7 & 3.6 & 1.2 & 1.1 & $<0.05$ \\
\hline
\end{tabular}



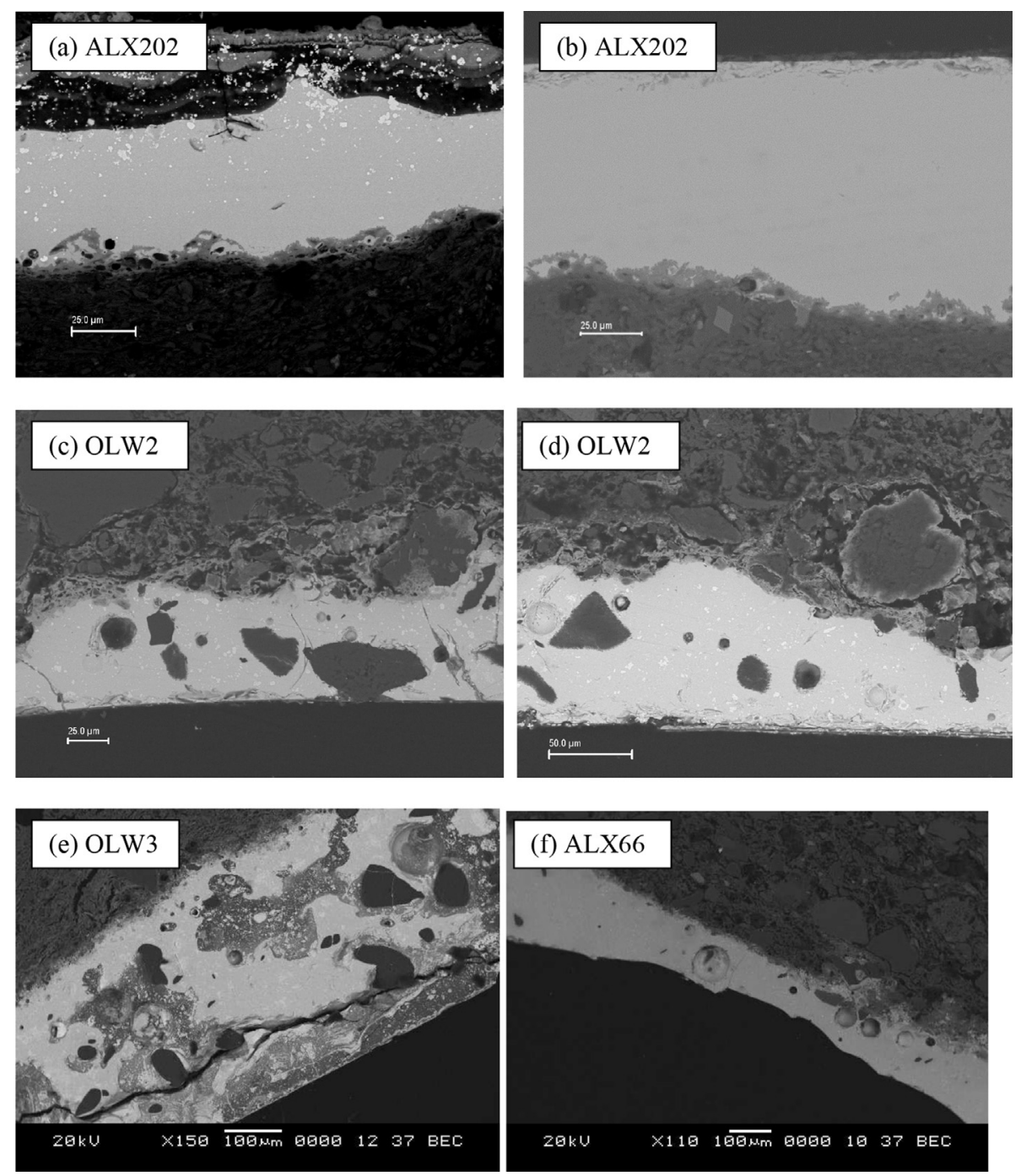

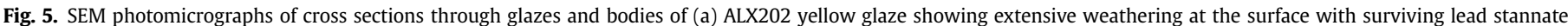

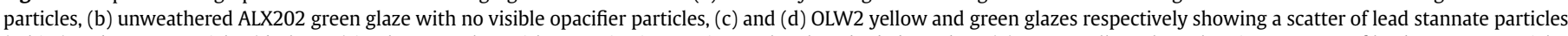

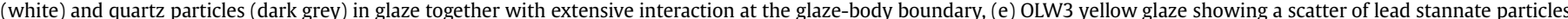

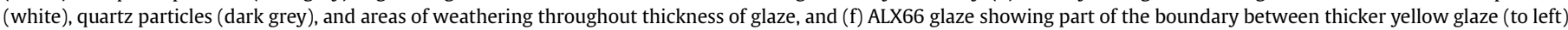
and thinner green glaze (to right).

\section{Production of opacified glazes}

\subsection{Tin-based opacifiers}

On the basis of their chemical compositions, opacified yellow glazes applied to Egyptian CGW and Syria YGF were most probably produced by applying a lead-silica-tin mixture to the clay body which was then fired.

By means of high-temperature XRD measurements using a synchrotron source, Tite et al. $(2008,71)$ have determined the phase transformations that occur when mixtures of lead oxide, silica and tin oxide are fired progressively from room temperature to about $1000{ }^{\circ} \mathrm{C}$. For mixture USN3 (63.8 wt\% PbO + $27.1 \mathrm{wt} \%$ $\mathrm{SiO}_{2}+9.1 \mathrm{wt} \% \mathrm{SnO}_{2}$ ) which was closest in composition to the glazes (Table 1), lead and tin oxides start to react to form orthorhombic lead stannate $\left(\mathrm{Pb}_{2} \mathrm{SnO}_{4}\right)$ from about $450{ }^{\circ} \mathrm{C}$. Then, from about $550{ }^{\circ} \mathrm{C}, \mathrm{Pb}_{2} \mathrm{SnO}_{4}$ starts to transform to cubic lead stannate $\left(\mathrm{PbSnO}_{3}\right)$ by the incorporation of silica, and it is this cubic form that produces the strong yellow colour. Also, from about $550{ }^{\circ} \mathrm{C}$, lead oxide and silica start to react to form a lead silicate $\left(\mathrm{Pb}_{2} \mathrm{SiO}_{4}\right)$ which subsequently begins to develop into a melt from about $650{ }^{\circ} \mathrm{C}$. Finally, again from about $650{ }^{\circ} \mathrm{C}, \mathrm{PbSnO}_{3}$ starts to transform by dissolution and recrystallisation to cassiterite $\left(\mathrm{SnO}_{2}\right)$, the transformation being complete by about $750{ }^{\circ} \mathrm{C}$. Because of the rapid heating rate $\left(300^{\circ} \mathrm{C} / \mathrm{h}\right)$, it is unlikely that equilibrium was achieved during the XRD measurements, and therefore, the exact temperature for the transformation of $\mathrm{PbSnO}_{3}$ to $\mathrm{PbO}$ plus $\mathrm{SnO}_{2}$ will vary according to the heating rate used in firing the mixture (Tite et al., $2008,74)$. However, since the transformation occurs subsequent to the formation of a melt, the temperatures observed during the XRD measurements provide a reasonably valid indication of the approximate firing temperature for survival of $\mathrm{PbSnO}_{3}$ in the production of the glaze.

These results indicate that, in order to avoid significant transformation of the yellow cubic lead stannate into white tin oxide, the firing temperature for the glaze must have been kept to a minimum. Therefore, Islamic potters could have discovered white tinopacified glazes by overfiring an intended lead stannate yellow 

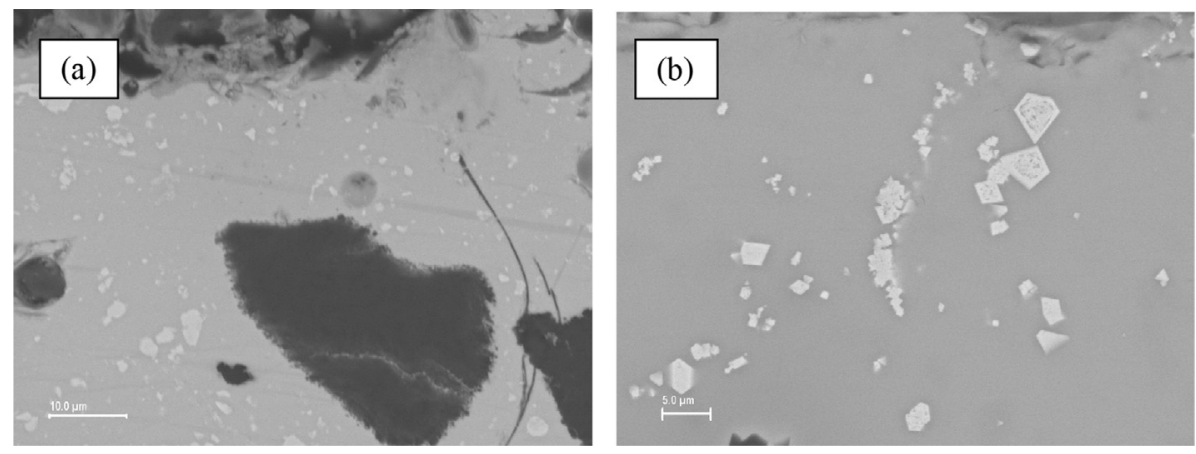

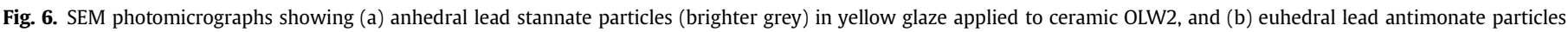
(white) in yellow glaze applied to ceramic ALX66.

glaze, although the tin oxide contents and thickness of the glazes might sometimes have been insufficient to achieve fully opaque white glazes.

Although it is not impossible that the yellow glaze was produced by applying an unfired lead-tin-silica mixture to the body, the large and irregular (i.e., anhedral) nature of the lead stannate particles (Fig. 6a) suggest that the lead-tin-silica mixture was first prefritted, the large size of the particles suggesting a fairly long firing time. After crushing to a fine powder, this frit would have been mixed with more lead oxide and silica, and applied to the clay body, probably as a suspension in water, before refiring to produce the glaze. The production procedure would therefore have been related to that of the anime used to produce yellow glass in Venice in the 18 th and 19 th centuries, except that $w t \% \mathrm{PbO} / \mathrm{wt} \% \mathrm{SiO}_{2}$ ratio of the glaze was much lower than that of typical anime (i.e., 2 compared to $\sim 8$ for the anime) (Moretti and Hreglich, 1984).

In view of the fact that the composition of the glazes are approaching the $70 \mathrm{wt} \% \mathrm{PbO}-30 \mathrm{wt} \% \mathrm{SiO}_{2}$ eutectic mixture that melts at $714^{\circ} \mathrm{C}$, a firing temperature for the glaze of less than about $750{ }^{\circ} \mathrm{C}$ would probably have been sufficient. However, near- eutectic mixtures have relatively long firing ranges, and therefore, could still be viable at higher temperatures, provided that the firing time for the glaze was fairly short. Even so, since the microstructures of the clay bodies, as observed in the SEM, suggest firing temperatures of at least $800-850{ }^{\circ} \mathrm{C}$ for the aluminium-rich clay, and at least $850-900{ }^{\circ} \mathrm{C}$ for the calcareous clays, it seems probable that the bodies had been biscuit fired. The occasional quartz particles observed in some of the glazes (Fig. $5 c-e$ ) are probably the result of the survival of some partially reacted silica particles in the glazing mixture.

The green glazes were most probably produced by applying a lead-silica mixture, with a similar $\mathrm{PbO} / \mathrm{SiO}_{2}$ ratio to that used in the production of the yellow glazes, either directly to the biscuit fired clay body, or over the unfired yellow glaze mixture. In neither case would the addition of tin to the mixture have been necessary since green glazes applied directly onto the body (ie ALX202 and OLW4) contain no lead stannate particles, and when applied over the yellow glaze (ie OLW2 and OLW3), the observed lead stannate particles could have been derived from the underlying opacified yellow glaze. The fact that the copper oxide contents are higher at
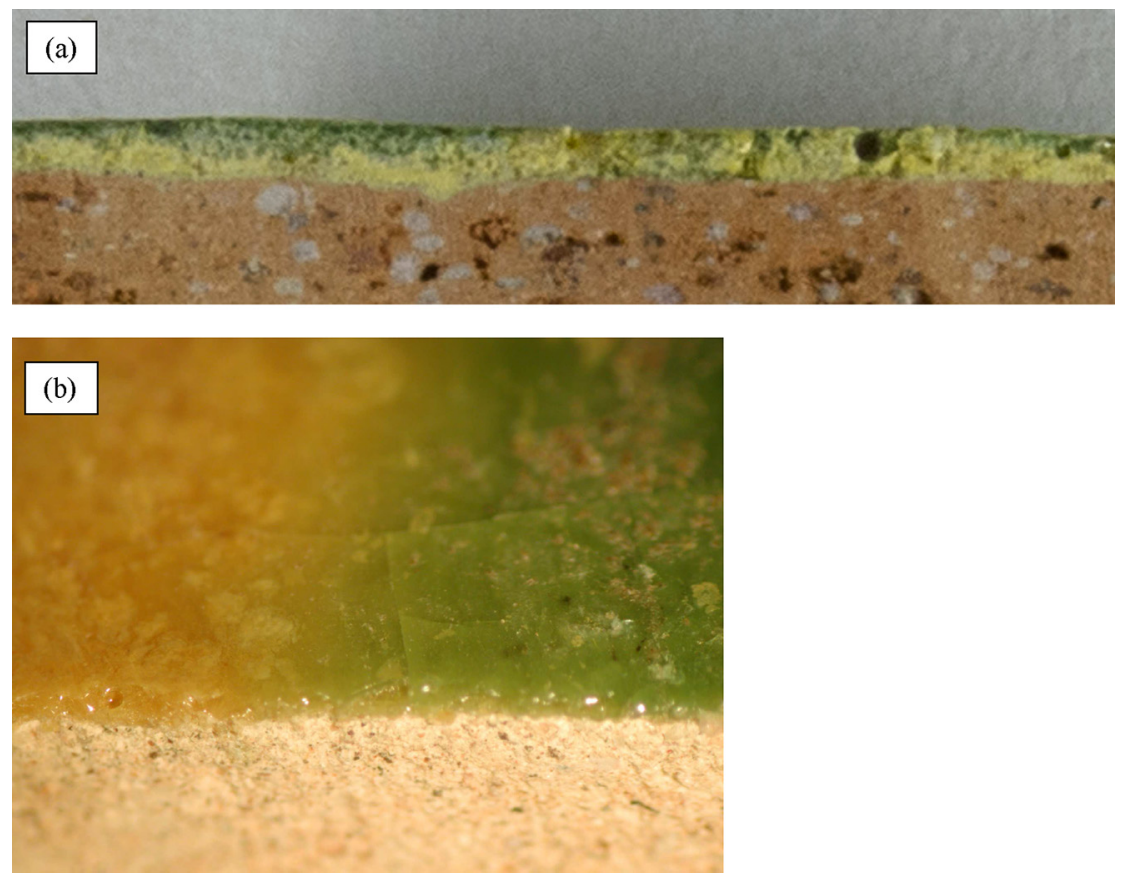

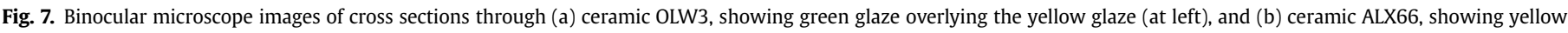
glaze (LHS) adjacent to green glaze (RHS). 

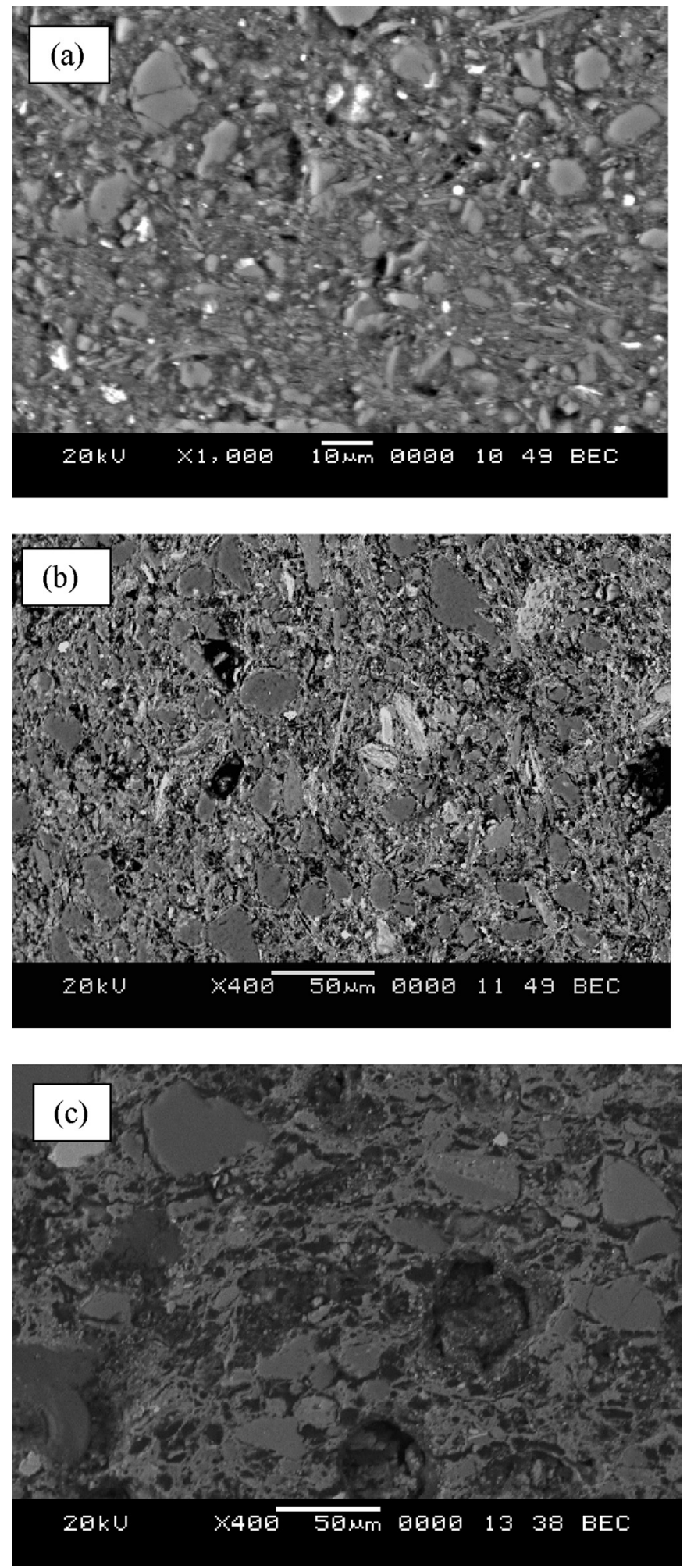

Fig. 8. SEM photomicrographs of cross sections through bodies of (a) ceramic ALX202 showing compacted microstructure associated with aluminium-rich clay with slight vitrification of the clay matrix bonding the non-plastic particles; and (b) ceramic OLW1 and (c) ceramic ALX66 showing more porous structure associated with calcareous clay with extensive vitrification of clay matrix bonding together the non-plastic particles which tend to be coarser for ALX66 as compared to OLW1. the front of the glazes as compared to the back adjacent to the bodies (Table 2) is to be expected when the green glaze mixture was applied over the unfired yellow glaze. However, the presence of copper oxide gradients, although with lower $\mathrm{CuO}$ wt\% front/back ratios, when the green glaze mixture is applied direct to the body suggests that the copper colourant, perhaps with some lead oxide to help integration during firing, was applied over the lead-silica mixture rather than being included in it.

The presence of significant alumina contents in the yellow and green glazes applied to both the Egyptian CGW ceramic ALX202 ( $4 \mathrm{wt} \% \mathrm{Al}_{2} \mathrm{O}_{3}$ ) and, as discussed below, the Egyptian ceramic ALX66 related to Fayyumi Type 1 ware $\left(3 \mathrm{wt} \% \mathrm{Al}_{2} \mathrm{O}_{3}\right.$ ) (Table 1) could be due either to the addition of clay to the suspension of crushed glazing frit or to diffusion of alumina from the clay body. However, the absence of steep alumina concentration gradients for these two ceramics (Table 2), such as were observed in replication experiments involving the application of lead oxide-plus-quartz frits (Walton and Tite, 2010, 745-746), strongly favours the former explanation. The addition of clay to a glazing suspension is known to help to maintain the frit particles in suspension, to give plasticity to the suspension, and to improve the bonding between the frit particles and the body (Parmelee, 1948, 72-75, Tite et al., 1998).

\subsection{Antimony-based opacifiers}

Although it is possible that the yellow glaze applied to Egyptian sherd ALX66 related to Fayyumi Type 1 ware was produced using an unfired lead-silica-antimony mixture, it is equally probable that this glaze was produced using a prefired and crushed lead-silicaantimony frit which was applied to the biscuit fired clay body which was then refired. This frit would similarly have been related to the anime used in the production of Venetian yellow glass, with its $\mathrm{wt} \% \mathrm{PbO} / \mathrm{wt} \% \mathrm{SiO}_{2}$ ratio again being much lower than that of typical anime (i.e., $~ 1.4$ compared to $\sim 8$ for the anime) (Moretti and Hreglich, 1984).

As discussed by Molina et al. (2014), the substitution for antimony of impurities such as iron, zinc and tin favours the formation of lead antimonate of the cubic $\mathrm{Pb}_{2} \mathrm{Sb}_{2} \mathrm{O}_{7}$ type rather than $\mathrm{Pb}_{3+\mathrm{x}} \mathrm{Sb}_{2} \mathrm{O}_{8+\mathrm{x}}$. Therefore, due to the incorporation of iron and titanium, as well as sometimes calcium and tin, into the structure of the lead antimonate particles, cubic $\mathrm{Pb}_{2} \mathrm{Sb}_{2} \mathrm{O}_{7}$ was formed in the ALX66 glazes, the formula for typical particles being $\mathrm{Pb}_{2} \mathrm{Sb}_{1.6} \mathrm{Fe}_{0.1}$ $\mathrm{Ti}_{0.3} \mathrm{O}_{6.6}$. The origin of the iron and titanium in the glazing mixture could have been the result of contamination from iron minerals, such as pyrites, introduced with the galena used in its production, and/or from the clay crucibles in which the glazing mixture was produced. Alternatively, as suggested by Freestone and Stapleton (in press) in the case of Roman glass production, the iron could have been added deliberately. In view of the comparatively low antimony content of the yellow glaze $\left(0.9 \mathrm{wt} \% \mathrm{Sb}_{2} \mathrm{O}_{5}\right)$, it is possible the iron oxide $\left(2.6 \mathrm{wt} \% \mathrm{Fe}_{2} \mathrm{O}_{3}\right.$ ) is also contributing to the yellow colour in the ALX66 glaze, iron oxide being the standard nonopaque yellow colourant in the high-lead glazes used in the production of Chinese Changsa and sancai ware and their Islamic imitations (Wood et al., 2009).

Since, the green glaze was applied directly to the biscuit fired ALX66 body, the glaze must itself have been opacified. Therefore, a lead-silica-antimony mixture, similar in composition to that used in the production of the yellow glaze, would have been used. Because of the presence of a copper oxide gradient with a low $\mathrm{CuO}$ wt\% front/back ratio, it seems probable that the copper colourant, perhaps again with some lead oxide to help integration during firing, was applied over the lead-silica-antimony mixture rather than being included in it. 


\section{Discussion}

The use of yellow glazes opacified with lead stannate for the Egyptian CGW and Syrian YGF ceramics during the 8th century AD can be explained in terms of an awareness of the technology employed by Byzantine glassmakers who had continued the Roman use of lead stannate as a yellow opacifier, particularly in glass tesserae for mosaics (Freestone et al., 1990). However, rather than being the result of direct contact with Byzantine glassmakers, the employment of lead stannate is more likely to have been as a result of contact with Syrian and Egyptian glassmakers who continued to work in the Byzantine tradition whilst now operating under Islamic rule. The use of high lead glazes for these ceramics can similarly be explained in terms of the Egyptian and Syrian potters continuing the Roman, and subsequent Byzantine, use of high lead glazes (Waksman et al., 2007, 2008; Walton and Tite, 2010). Further, the use of yellow lead stannate opacified glazes of very similar composition in Samarra, Kish and Susa establishes that, together with the proposed stylistic transfer eastwards from the Mediterranean to Mesopotamia, there was an equivalent technological transfer.

One can further argue that the yellow glazed pottery introduced into Mesopotamia could have provided the social context for the demand for tin-opacified white glazed pottery in Abbasid Iraq in early 9th century AD. The switch from yellow lead stannate glazes to white tin-opacified glazes would then have reflected the desire to imitate imported Chinese whitewares and porcelains. Conversely, it is less clear whether yellow glazed pottery provided the technological context for the production of white glazed pottery. Although Islamic potters could have discovered white tinopacified glazes by overfiring an intended lead stannate yellow glaze, the tin oxide contents and thickness of the glazes might sometimes have been insufficient to achieve fully opaque white glazes. However, perhaps more important in this context is the fact that the yellow lead stannate and white tin-opacified glazes can have very different compositions.

The yellow glazes from Egypt, Syria and Mesopotamia are consistently of the high lead type, containing some $60 \mathrm{wt} \% \mathrm{PbO}$ and only up to about 2 wt\% alkali (i.e., $\mathrm{Na}_{2} \mathrm{O}+\mathrm{K}_{2} \mathrm{O}$ ), whereas the Abbasid white tin-opacified glazes vary in lead content from 1 to $50 \mathrm{wt} \% \mathrm{PbO}$ and in alkali content from 3 to $15 \mathrm{wt} \%\left(\mathrm{Na}_{2} \mathrm{O}+\mathrm{K}_{2} \mathrm{O}\right)$. In the case of Abbasid ceramics found mainly at Samarra and produced in imitation of Chinese Changsha, sancai or plain white wares, the glazes contain some 30-50 wt\% $\mathrm{PbO}$ and 3-6 wt\% $\left(\mathrm{Na}_{2} \mathrm{O}+\mathrm{K}_{2} \mathrm{O}\right)$ (Rawson et al., 1989; Mason and Tite, 1997; Wood et al., 2009), and thus, provide the closest match to the high lead, yellow glazes. In contrast, the glazes associated with the cobalt blue and lustre decorated wares, which it is suggested on the basis of their petrofabric were produced predominantly at Basra (Mason, $1991)$, are essentially alkali-lime glazes (9-15 wt\% $\left(\mathrm{Na}_{2} \mathrm{O}+\mathrm{K}_{2} \mathrm{O}\right)$ and $4-7 \mathrm{wt} \% \mathrm{CaO}$ ) containing only small amounts of lead (1-11 wt\% PbO) (Rawson et al., 1989; Mason and Tite, 1997). They are therefore very different in composition to the high lead, yellow glazes. The former plain or green-decorated white wares were evidently made in many places in Syria and Iraq, and some at least clearly used high-lead glazes, whereas the low-lead Basra wares are a restricted group with an apparent monopoly on the use of blue or lustre decoration. However, this observed pattern may well change as more samples are analysed.

In view of the very different glaze compositions employed for yellow lead stannate glazes and white tin-opacified glazes associated with cobalt blue and lustre decorated wares, it seems probably that the latter represent a separate but parallel technological tradition. Pilosi et al. (2012) have analysed a fragment of 9th century AD white cameo glass found at Nishapur, and have shown that it is essentially a tin-opacified, alkali-lime glass containing some 20 wt\% $\left(\mathrm{Na}_{2} \mathrm{O}+\mathrm{K}_{2} \mathrm{O}\right)$ and $6 \mathrm{wt} \% \mathrm{CaO}$, less than $1 \mathrm{wt} \% \mathrm{PbO}$, and $3.3 \mathrm{wt} \% \mathrm{SnO}_{2}$. Mark Wypyski (private communication) has analysed 8th -10 th century AD multicoloured glass beads from Nishapur (Wypyski, in press) in the Metropolitan Museum of Art, New York, together with 9th century AD mosaic glass tiles from Samarra in the Berlin Museum and the Metropolitan Museum of Art, New York. Myrto Georgakopoulou (private communication), using an HH-XRF, has analysed a similar 9th century mosaic glass tile (GL.513.2009) in the Museum of Islamic Art in Qatar. Again, the white glasses were found to be of the tin-opacified alkali-lime type containing only a few wt\% PbO. Therefore, the 8th - 10th century AD opaque white glasses from Nishapur and Samarra are very similar in composition to the low-lead, cobalt blue and lustre decorated glazes produced predominantly at Basra.

In the context of lustre decorated wares, it should be noted that the formation of lustre requires the presence of alkalis in reasonably high amounts, the process involving the diffusion of copper and silver ions from the lustre paint into the glaze where they substitute sodium and/or potassium ions which are removed from the glaze (Pradell et al., 2005; Molera et al., 2007). The subsequent increase in the lead oxide content of the lustre glazes (Mason and Tite, 1997) can then be explained in terms of a desire to reduce the extent of glaze crazing, resulting from the thermal expansion mismatch between high alkali glazes and earthenware bodies (Tite et al., 1998). Further, the addition of lead oxide to the glaze also reduces the diffusivity of copper and silver in the glaze resulting in thinner and more concentrated lustre layers which create the appearance of a metallic golden foil (Pradell et al., 2007; Gutierrez et al., 2010).

Recipes for tin-opacified yellow glass production are given by Jabir ibn Hayyan (c.721-815 AD) in his 8th century AD Arabic treatise on the colouring of glass (e.g. recipe 4 , fol.1b and recipe 12 , fol.2a) (Al-Hassan, 2009). The opaque yellow glasses from Nishapur (Wypyski, in press) and Samarra, analysed by Wypyski and Georgakopoulou (private communications), are similar in composition to the 5th -10 th century yellow and green Byzantine glass tesserae (Freestone et al., 1990; Wypyski, 2005) which are of the alkali-lead type and contain some $15-17 \mathrm{wt} \%\left(\mathrm{Na}_{2} \mathrm{O}+\mathrm{K}_{2} \mathrm{O}\right), 6-8 \mathrm{wt} \% \mathrm{CaO}$, 6-10 wt\% $\mathrm{PbO}$ and $1-2 \mathrm{wt} \% \mathrm{SnO}_{2}$. Therefore, the Byzantine and Islamic opaque yellow glasses are very different in composition to the high-lead CGW and YGF yellow glazes produced in Egypt and Syria. The very much higher lead content of the glaze (about $60 \mathrm{wt} \%$ $\mathrm{wt} \% \mathrm{PbO}$ ) is in part due to the fact that the lead-silica-tin frit provides the entire yellow glaze whereas, in the production of yellow glass, the lead content of the frit is diluted by mixing it into a colourless alkali-lime glass.

In Egypt, when opaque yellow and green glazes were produced alongside white tin-opacified glazed wares introduced from Iraq, probably in the 9th - 10th century AD, there is evidence that, as observed for ceramic ALX66 and for two Fayyumi Type 1 ceramics, there was a switch from the use of lead stannate to the use of lead antimonate as the yellow opacifier. However, tin oxide continued to be used in Egypt and throughout the Islamic world for white opacified glazes (Mason and Tite, 1997). A possible reason for the switch from lead stannate to lead antimonate is that replication experiments suggest that lead antimonate is more stable, its conversion to calcium antimonate occurring at a higher firing temperature than the conversion of lead stannate to tin oxide (Tite et al., 2008; Molina et al., 2014). Also, the yellow colour associated with lead antimonate tends to be stronger than that associated with lead stannate.

In contrast to the situation for the Egyptian Fayyumi Type 1 and related yellow glazed ceramics, the use of lead stannate, observed in Nishapur and Samarra yellow glass of 8th-10th century, is 
continued in the yellow enamel applied to Islamic glasses of the 13th and 14th centuries AD (Freestone and Stapleton, 1998; Wypyski, 2010). In this case, the lead stannate yellow enamels are of the high lead type ( $\sim 5 \mathrm{wt} \% \mathrm{PbO}, \sim 2 \mathrm{wt} \%\left(\mathrm{Na}_{2} \mathrm{O}+\mathrm{K}_{2} \mathrm{O}\right)$ ), and are therefore comparable in composition to yellow Egyptian CGW and Syrian YGF glazes.

\section{Conclusions}

The above results establish that, as proposed by Watson (2014), tin was first used in the form of lead stannate to produce yellow opaque glazes in Egypt (CGW) and Syria (YGF) in 8th century AD, before being used in the form of tin oxide to produce opaque white glazes in Abbasid Iraq in 9th century AD. This use of lead stannate can be explained in terms of technological transfer from contemporary Egyptian and Syrian glassmakers who had continued the Byzantine tradition of glassmaking whilst working under Islamic rule. Further, it can be argued that the production of yellow glazed wares provided the social context for the emergence of tinopacified white glazes in Abbasid Iraq in the 9th century AD. However, it seems probable that the white tin-opacified glazes associated with cobalt blue and lustre decorated wares represent a separate but parallel technological tradition with its origins in the production of Islamic opaque white glass.

Regarding further work, in order to understand the production of these glazed wares, it would be helpful to replicate such high lead, tin-opacified yellow and green glazes in the laboratory. These replications should include the use of both prefritted and unfired yellow glazing mixtures, and for the green glaze, both the application of the copper colourant over and its inclusion in the leadsilica glaze mixture. The factors determining the firing temperature at which lead stannate converts to tin oxide should be investigated, and in particular, whether lead stannate in a near-eutectic mixture survives beyond the $750{ }^{\circ} \mathrm{C}$ conversion temperature predicted by the synchrotron experiments. Thin glazes with low lead stannate contents, comparable to those observed for the yellow CGW and YGF glazes analysed by SEM, should be replicated in order to establish whether or not opaque white glazes really do result from overfiring.

Second, in order to try to understand better whether there is any technological link between the high lead yellow glazes, first produced in Egypt and Syria, and the low lead white glazes produced in Abbasid Iraq, additional analytical data are required for yellow glazes from Mesopotamia, and similarly for opacified white glazes produced in Egypt, Syria and Mesopotamia. In this context, Watson (1999, 82-83) has reported opacified white glazed ware found at Raqqa in a late 8th/early 9th century AD context alongside YGF wares. He describes what appear to be three different fabrics, each distinct from the Basra type, but related to each other by shape and glazing method, some of which are decorated with green splashes.

Finally, additional research is required in order to establish how extensively and over what time period lead antimonate was used as the yellow opacifier in Egyptian yellow glazed wares, and the extent to which it was used outside Egypt. In Syria, the YGF wares appear to be almost entirely replaced by opaque white glazed wares during the 9th century AD. However, in more distant parts of the Islamic empire, such as North Africa and eastern Iran, stylistic descendents of YGF types appear to have been made, with decoration including a strong yellow. In this context, Pradell (private communication) has identified lead antimonate in the yellow glaze applied to a ceramic most probably from Tunisia dated to late 9th - 10th century AD, and held in the Museu de Ceramica de Barcelona (MCB18710). Further analyses are again required to take forward this study.

\section{Acknowledgements}

The project is funded by CICYT grants MAT2010-20129-C02-01 and MAT2013-41127-R and Generalitat de Catalunya grant 2014SGR581. We are extremely grateful to Mark Wypyski (Metropolitan Museum of Art, New York) for giving us access to his unpublished analytical data for multicoloured glasses from Nishapur and Samarra. Mark Norman and Daniel Bone (Objects Conservation, Ashmolean Museum) are thanked for arranging access to the Ashmolean Coptic Glazed Ware bowl (EA1974.48) for HH-XRF analysis, and Museu de Ceramica de Barcelona is thanked for permission to sample the North African ceramic, MCB18710. We are also grateful to the Museum of Islamic Art in Qatar for providing access to a 9th century mosaic glass tile (GL.513.2009), and to Myrto Georgakopoulou for undertaking its analysis using a HH-XRF. An anonymous referee is thanked for his very helpful comments that have resulted in significant improvements to the paper.

\section{References}

Al-Hassan, A.Y., 2009. An eight century Arabic treatise on the colouring of glass: Kitab al-Durra al-Maknūna (The book of the hidden pearl) of Jābir ibn Hayyān (c. 721-c. 815). Arabic Sci. Philos. 19, 121-156.

Campbell, J.L., Boyd, N.I., Grassi, N., Bonnick, P., Maxwell, J.A., 2010. The Guelph PIXE software package IV. Nucl. Instrum. Methods B 268, 3356-3363.

Casadio, F., Bezur, A., Domoney, K., Eremin, K., Lee, L., Shortland, A., Zumbulaydis, N., 2012. X-ray fluorescence applied to overglaze enamel decoration on eighteenth- and nineteenth-century porcelain from central Europe. Stud. Conserv. 57, 61-72.

Freestone, I.C., Stapleton, C.P., 1998. Composition and technology of Islamic enamelled glass of the thirteenth and fourteenth centuries. In: Ward, R. (Ed.), Gilded and Enamelled Glass from the Middle East. British Museum Press, London, pp. $122-128$.

Freestone, I.C. Stapleton, C.P., 2015. Composition, technology, and production of coloured glasses from Roman mosaic vessels. In: Bayley, J., Freestone, I., Jackson, C. (Eds.), Glass of the Roman World. Oxbow Books, Oxford (in press).

Freestone, I.C., Bimson, M., Buckton, D., 1990. Compositional categories of Byzantine glass tesserae. In: Annales du 11e Congrès de l'Association Internationale pour l'Histoire du Verre (Bale 1988), pp. 271-279.

Gutierrez, P.C., Pradell, T., Molera, J., Smith, A.D., Climent-Font, A., Tite, M.S., 2010. Color and golden shine of silver Islamic luster. J. Am. Ceram. Soc. 93, 2320-2328.

Hayes, J.W., 1972. Late Roman Pottery: a Catalogue of Roman Fine Wares. British School at Rome, London.

Lane, A., 1947. Early Islamic Pottery. Faber and Faber, London.

Maniatis, Y., Tite, M.S., 1981. Technological examination of Neolithic-Bronze Age pottery from central and south-east Europe and the Near East. J. Archaeol. Sci. 8, 59-76.

Mason, R.B., 1991. Petrology of Islamic ceramics. In: Middleton, A., Freestone, I (Eds.), Recent Developments in Ceramic Petrology, British Museum Occasional Paper 81, pp. 185-210. London.

Mason, R.B., Tite, M.S., 1997. The beginnings of the tin-opacification of pottery glazes. Archaeometry 39, 41-58.

Molera, J., Bayés, C., Roura, P., Crespo, D., Pradell, T., 2007. Key parameters in the production of medieval lustre colors and shines. J. Am. Ceram. Soc. 90 2245-2254. http://dx.doi.org/10.1111/j.1551-2916.2007.01563.x.

Molina, G., Odin, G.P., Pradell, T., Shortland, A.J., Tite, M.S., 2014. Production technology and replication of lead antimonate yellow glass from New Kingdom Egypt and the Roman Empire. J. Archaeol. Sci. 41, 171-184.

Moretti, C., Hreglich, S., 1984. Opacification and colouring of glass by the use of "anime". Glass Technol. 25, 277-282.

Northedge, A., 2001. Thoughts on the introduction of polychrome glazed pottery in the Middle East. In: Villeneuve, E., Watson, P.M. (Eds.), La céramique Byzantine et proto-islamique en Syrie-Jordanie (IVe- VIlle siècles apr. J.-C.). Institut français d'archéologie du Proche-Orient, Beirut, pp. 207-214.

Parmelee, C.W., 1948. Ceramic Glazes. Industrial Publication Inc., Chicago.

Pichon, L., Moignard, B., Lemasson, Q., Pacheco, C., Walter, P., 2014. Development of a multi-detector and a systematic imaging system on the AGLAE external beam. Nucl. Instrum. Methods Phys. Res. B 318, 27-31. Part A.

Pichon, L., Beck, L., Walter, Ph, Moignard, B., Guillou, T., 2010. A new mapping acquisition and processing system for simultaneous PIXE-RBS analysis with external beam. Nucl. Instrum. Methods B 268, 2028-2033.

Pilosi, L., Stamm, K., Wypyski, M.T., 2012. An Islamic cameo glass fragment in the Metropolitan Museum of Art. In: Annales du 18e Congrès de l'Association Internationale pour l'Histoire du Verre (Thessaloniki 2009), pp. 341-345.

Pradell, T., Molera, J., Roque, J., Smith, A.D., Crespo, D., Pantos, E., Vendrell, M., 2005. Ionic-exchange mechanism in the formation of medieval luster decorations. J. Am. Ceram. Soc. 88, 1281-1289.

Pradell, T., Climent-Font, A., Molera, J., Zucchiatti, A., Ynsa, M.D., Roura, P., Crespo, D., 2007. Metallic and non-metallic shine in luster: an elastic ion backscattering 
study. J. Appl. Phys. 101 (9), 8. http://dx.doi.org/10.1063/1.2734944 article no 103518.

Rawson, J., Tite, M.S., Hughes, M.J., 1989. The export of Tang sancai wares: some recent research. Trans. Orient. Ceram. Soc. 52, 39-61.

Scanlon, G., 1993. Fayyumi pottery Type I: a long-lived misnomer in Egyptian Islamic ceramics. In: Alexandrian Studies in Memoriam Daoud Abdu Daoud. Bulletin de la Société Archéologique d'Alexandrie 45, pp. 1-39.

Scanlon, G., 1998. Slip-painted early lead-glazed wares from Fustat: a dilemma of nomenclature. In: Colloque International d'Archéologie Islamique. IFAO, Cairo, pp. $21-53$.

Tite, M.S., 2011. The technology of glazed Islamic ceramics using data collected by the late Alexander Kaczmarczyk. Archaeometry 53, 329-339.

Tite, M., Wood, N., 2005. The technological relationship between Islamic and Chinese glazed ceramics prior to 16th century AD. In: China-Mediterranean Sea - Routes and Exchange of Ceramics Prior to 16th Century, Taoci No 4, pp. 31-39.

Tite, M.S., Pradell, T., Shortland, A., 2008. Discovery, production and use of tin-based opacifiers in glasses, enamels and glazes from the Late Iron Age onwards: a reassessment. Archaeometry 50, 67-84.

Tite, M.S., Freestone, I., Mason, R., Molera, J., Vendrell-Saz, M., Wood, N., 1998. Lead glazes in antiquity - methods of production and reason for use. Archaeometry $40,241-260$.

Turner, W.E.S., Rooksby, H.P., 1959. A study of opalising agents in ancient opa glasses throughout three thousand four hundred years. Glastech. Ber. 32K (VII), $17-28$.

Waksman, S.Y., Bouquillon, A., Cantin, N., Katona, I., 2007. The first Byzantine "Glazed White Wares" in the early medieval technological context. In: Waksman, S.Y. (Ed.), Archaeometric and Archaeological Approaches to Ceramics
(Papers Presented at EMAC'05). BAR International Series 1691, Oxford, pp. 129-135.

Waksman, S.Y., Bouquillon, A., Cantin, N., Katona, I., 2008. Approche archéométrique des premières "Byzantine Glazed White Ware" et de productions glaçurées romaines and romaines tardive. Rei Cretariæ Rom. Acta 40, 1-6.

Walton, M.S., Tite, M.S., 2010. Production technology of Roman lead glazed pottery and its continuance into late antiquity. Archaeometry 52, 733-759.

Watson, O., 1999. Report on the glazed ceramics. In: Miglus, P. (Ed.), Raqqa I: Die Frühislamische Keramik von Tall Aswad. Deutsches Archaeologisches Institut, Mainz, pp. 81-87 taf. 94-9.

Watson, O., 2014. Revisiting Samarra: the rise of Islamic glazed pottery. Beitr. zur Islam. Kunst Archäol. 4, 125-144.

Whitcomb, D., 1989. Coptic glazed ceramics from the excavations at Aqaba, Jordan. J. Am. Res. Centre Egypt 26, 167-182.

Wood, N., Doherty, C., Rosser-Owen, M., 2009. A Technological Study of Iraqi Copies of Chinese Changsha and Chinese Sancai Wares Found at Samarra, pp. 154-180. ISAC' 09.

Wood, N., Tite, M., Doherty, C., Gilmore, B., 2007. A technological examination of 910th century AD Abbasid blue-and-white ware from Iraq, and its comparison with 8th century AD Chinese blue-and-white sancai ware. Archaeometry 49, 665-684.

Wypyski, M.T., 2005. Technical analysis of glass mosaic tesserae from Amorium. Dumbart. Oaks Pap. 59, 183-192.

Wypyski, M.T., 2010. Compositional Study of Medieval Islamic Enameled Glass from the Metropolitan Museum of Art. In: Metropolitan Museum Studies in Art, Science, and Technology, vol. 1, pp. 109-132.

Wypyski, M.T., 2015. Chemical analysis of early Islamic glass from Nishapur. J. Glass Stud. 57 (in press). 